\title{
AS REGIÕES DE VALORAÇÃO ONTOJURÍDICA E OS MAPAS CONCEITUAIS COMO RECURSOS DE ENSINO E APRENDIZAGEM NO DIREITO PENAL ${ }^{1}$
}

THE REGIONS OF JURIDICAL ANALYSIS AND CONCEPTUAL MAPS AS RESOURCES FOR TEACHING AND LEARNING IN CRIMINAL LAW

LAS REGIONES DE VALORACIÓN ONTOLÓGICO JURÍDICA Y LOS MAPAS CONCEPTUALES COMO RECURSOS DE ENSEÑANZA Y APRENDIZAJE EN EL DERECHO PENAL

Hélio Luiz Fonseca Moreira² Fátima Cristina da Costa Pessoa ${ }^{3}$

Resumo: O presente artigo aborda os conceitos de Regiões de Valoração Ontojurídica e Referentes de Valoração por meio de mapas conceituais para demonstrar que a articulação entre esses constructos pode configurar-se em recurso de ensino e aprendizagem capaz de tornar mais evidente a

1 Este artigo é resultado das atividades docentes realizadas no projeto de monitoria "Direito Penal em mapas conceituais", desenvolvido na Faculdade de Direito/UFPA, com o apoio financeiro da PROEG/UFPA (MONIT141002472049 ), sob a coordenação do autor.

2 Prof. Adjunto de Direito Penal da Faculdade de Direito/UFPA - Campus Belém. Advogado, Sociólogo e doutor em Ciências Sociais pelo PPGCS/UFPA. helfm@yahoo.com.br

3 Prof. a Associada de Língua Portuguesa da Faculdade de Letras/UFPA - Campus Belém. Doutora em Estudos Linguísticos pelo PosLin/UFMG e docente do PPGL/UFPA. fpessoa37@ gmail.com. 
análise da conduta típica, suas circunstâncias e sanção correlata, bem como conferir maior visibilidade à integração conceitual do conceito analítico de crime.

Palavras-chave: conduta, regiões de valoração ontojurídica, referentes de valoração; mapas conceituais.

Abstract: This article addresses the concept of regions of juridical analysis and referents of analysis through conceptual maps, to demonstrate that the relationship between these concepts can be configured as a teaching and learning resource capable of clarifying the analysis of typical conduct, its circumstances, and the correlated penalty, and give greater visibility to the conceptual integration of the analytical concept of crime.

Keywords: conduct, regions of juridical analysis, referents of analysis; conceptual maps.

Resumen: El presente artículo aborda los conceptos de Regiones de Valoración Ontológico Jurídica y Referentes de Valoración por medio de mapas conceptuales para demostrar que la articulación entre esos constructos puede configurar un recurso de enseñanza y aprendizaje capaz de hacer más evidente el análisis de la conducta típica, sus circunstancias y la sanción correlacionada, así como conferir mayor visibilidad a la integración conceptual del concepto analítico de crimen.

Palabras clave: Conducta; Regiones de valoración ontológico jurídica; Referentes de valoración; Mapas conceptuales.

INTRODUÇÃO

caracterização de uma conduta criminosa e a fixação de sua sanção
correlata articulam uma série de referentes conceituais que thes dão
sentido jurídico e ontológico, tais como os princípios da reserva legal, da anterioridade, da consunção, da subsidiariedade e da taxatividade; 
as normas penais incriminadoras, permissivas justificantes e dirimentes; além dos conceitos de conduta típica, dolo, culpa, resultado, nexo causal, nexo finalista, imputabilidade e consciência potencial da ilicitude. Ocorre, porém, que esses referentes estão dispersos no campo penal e essa dispersão conceitual frequentemente cria dificuldades para o acadêmico de direito construir uma visão integrativa do Direito Penal no processo de aprendizagem.

O presente artigo tem como principal objetivo demonstrar que articulação entre os constructos Conduta Típica, Referentes de Valoração Ontojurídica e Região de Valoração Ontojurídica pode constituir um organizador prévio ${ }^{4}$, possível de ser empregado como recurso de ensino e aprendizagem para sistematizar regionalmente os conceitos empregados na análise da conduta típica e sua sanção correlata, tornando a integração conceitual mais evidente.

A conduta sempre esteve no centro dos debates realizados no Direito Penal, uma vez que, classicamente, todo o sistema de racionalidade jurídico-penal gira em torno desse conceito ${ }^{5}$. Todavia, no que refere às Regiões de Valoração Ontojurídica, cabe ressaltar que não há literatura jurídica que o adote, pois esse constructo foi concebido como um organizador prévio para ser empregado nas aulas de Direito Penal em Mapas Conceituais, com base na Teoria da Aprendizagem Significativa ${ }^{6}$. Os mapas conceituais têm se constituído em importante recurso de ensino e produção de conhecimento empregado por pesquisadores e educadores nas diversas áreas do saber científico, tais como na Medicina7 , na Física e na Enfermagem9.

4 MOREIRA, Marco Antônio. Aprendizagem significativa: a teoria e textos complementares. São Paulo: Editora Livraria da Física, 2011. p. 103.

5 ZAFFARONI, Eugenio Raúl; BATISTA, Nilo et al. Direito Penal Brasileiro Vol. II - Delito: introdução histórica, ação e tipicidade. Rio de Janeiro: Revan, 2010. p. 82.

6 MOREIRA, Marco A. e MASINI, Elcie. A aprendizagem significativa: a teoria de David Ausubel. São Paulo: Moraes, 1982. p. 42.

7 GOMES, Andréia P.; DIAS-COELHO, Udson C. et al. O Papel dos Mapas Conceituais na Educação Médica. Revista Brasileira de Educação Médica; Rio de Janeiro, Vol. 35 n.0 2: p. 275-282, : Abril/Junho, 2011. Disponível em: www.scielo.br. Acesso em: fevereiro de 2015.

8 CICUTO, Camila Aparecida T.; MENDES Bárbara C.; CORREIA Paulo R. M.. Nova abordagem para verificar como os alunos articulam diferentes materiais instrucionais utilizando mapas conceituais. Revista Brasileira de Ensino de Física. São Paulo, Vol.3, no 3. p. 1-8 jul/ set, 2013. Disponível em: www.scielo.br. Acesso em: março de 2015.

9 FERREIRA, Paula B.; COHRS, Cibelli R.; DOMENICO, Edvane B. L. Software CMAP TOOLS® para a construção de mapas conceituais: a avaliação dos estudantes de enfermagem. Revista da Escola de Enfermagem da USP; São Paulo, Vol. 46, no 4, p. 967-972, Ago/2012. Disponível em: www.scielo.br. Acesso em: janeiro de 2015. 
O principal objetivo desse projeto é produzir conhecimento capaz de estimular o desenvolvimento da aprendizagem significativa no campo do Direito Penal. Nesse sentido, começa-se a mapear o conceito analítico de crime, suas regiões de valoração ontojurídica e seus referentes de valoração.

A região de valoração ontojurídica configura-se como um espaço conjuntural no qual se ancora e se ordenam-se os referentes conceituais empregados na valoração dos elementos objetivos e subjetivos que compõem a conduta típica, suas circunstâncias e sanção correlata, conformando um padrão procedimental de valoração único, que exclui todos os demais elementos e referentes que não Ihe fazem sentido. Assim, a valoração da conduta se desenvolve de forma regionalizada, com base em referentes estáveis e não arbitrários, em um processo cujo resultado é o explícito delineamento das diferenças e das similaridades entre as regiões e os referentes de valoração a elas relacionados.

Nesse sentido, os conceitos adquirem significados progressivamente diferenciados, que podem ser reconhecidos, relacionados e reconciliados de forma integrativa, por meio de um processo de interação e ancoragem ${ }^{10}$. O conceito analítico de crime, por exemplo, possui três regiões de valoração ontojurídica bem definidas, tipicidade, ilicitude e culpabilidade, cada uma com seus próprios referentes de valoração. Todavia, considerando-se que o projeto Direito Penal em Mapas Conceituais se encontra ainda em desenvolvimento, este trabalho se limitará a mapear, particularmente, o conceito de dolo direto, relativo à região de valoração ontojurídica da tipicidade, concebendo-o como subsunçor sobre o qual serão ancorados os conceitos de tentativa, crime impossível e erro sobre a pessoa.

\section{O MAPA CONCEITUAL COMO RECURSO DE ENSINO E APRENDIZAGEM}

Em geral, quando ingressa no curso de Direito da UFPA, antes mesmo de conhecer a ontologia e a lógica que ordena o Direito Penal, o acadêmico possui conhecimento sobre crime, dolo, culpa, pena, etc. Essa construção funda-se, 10 MOREIRA, Marco Antônio. Aprendizagem significativa: a teoria e textos complementares. p. 26. 
essencialmente, em informações veiculadas nos meios de comunicação de massa ou no uso indiscriminado de terminologias empregadas no senso comum, sem a devida interação com os conceitos tecnicamente elaborados no campo do Direito Penal. Ocorre, porém, que nos últimos semestres do curso evidencia-se que, em geral, os acadêmicos demonstram limitações técnicas e epistêmicas para operar o alcance teórico e o potencial analítico dos referentes conceituais empregados nesse campo, particularmente os relativos à Teoria do Delito.

Essas limitações se expressam não só no momento de analisar casos mais complexos, mas principalmente no momento de escolher os temas, recortar o objeto de estudo e definir a metodologia adequada para a elaboração do Trabalho de Conclusão de Curso (TCC). Ou seja, em termos de Direito Penal, observa-se que na trajetória do acadêmico os conceitos não se incorporam a sua estrutura cognitiva, constituindo-se como instrumentos que lhe permita pensar o mundo circunjacente e dimensionar os limites epistemológicos do Direito Penal para compreendê-lo e criticá-lo.

Consoante Novak $^{11}$, o uso do mapa conceitual em um contexto dinâmico, fundado no processo de construção, desconstrução e reconstrução de conceitos, constitui importante recurso de ensino e aprendizagem, pois possibilita uma abordagem reflexiva do conhecimento, tal como o conhecimento jurídico, razão pela qual é considerado relevante em aulas de Direito Penal.

Nesse sentido, acredita-se que, fundado na aprendizagem significativa, a operacionalização de mapas conceituais pode constituir-se em importante instrumento metodológico, de natureza pedagógica, empregado como organizador prévio na abordagem reflexiva do Direito Penal, a partir de um processo de construção, desconstrução e reconstrução de seus referentes conceituais, o que é fundamental para a constituição do conhecimento jurídicopenal, uma vez que são capazes de expressar graficamente conceitos ou modelos teóricos de interpretação da realidade, dimensionando o alcance teórico e o potencial analítico dos mesmos.

11 NOVAK, Joseph Donald. Learning, Creating, and Using Knowledge: Concept Maps as

Facilitative Tools in Schools and Corporations. 2. ed. Lawrence Erlbaum Associates, Mahwah, 2010. p. 14. Disponível em: http://books.google.com.br. Acesso em: novembro de 2014. 
Para Ausubel ${ }^{12}$, a aprendizagem significativa pressupõe a relação interativa, organizada e substancial entre a proposição de um novo conhecimento (logicamente estruturado) e o conhecimento existente na estrutura cognitiva do aprendiz. Nessa interação, o aprendiz estabelece relações de semelhança e diferença entre as informações novas e as já incorporadas para imputar significados organizados e substantivos aos materiais potencialmente significativos que devem ser incorporados à sua estrutura cognitiva, modificando o conhecimento prévio pela aquisição de novos significados.

Nessa perspectiva, a estrutura cognitiva do indivíduo é organizada e hierarquizada com base na conexão significativa que se estabelece entre ideias e conceitos. É nesta estrutura que são "ancorados" e reorganizados o novo conhecimento que o indivíduo vai progressivamente aprendendo e internalizando. Essas ideias e conceitos preexistentes que servem de "ancoradouro" para a nova informação são chamados "subsunçores", ou "organizadores prévios".

Consoante Moreira ${ }^{13}$, a clareza, a estabilidade e a organização dos organizadores prévios em dado corpo de conhecimento afetam a aprendizagem, pois influenciam na aquisição e na retenção do novo conhecimento. Dessa forma, o mapa conceitual pode ser usado como organizador prévio, configurando-se como material instrucional empregado para explicitar as relações não arbitrárias e substantivas do conhecimento novo, potencializando a aprendizagem significativa, conforme se observará na operacionalização do conceito de dolo direto, que, ao ser incorporado à estrutura cognitiva do acadêmico, servirá de organizador prévio para ancorar os conceitos de tentativa, crime impossível, erro sobre a pessoa, erro sobre nexo causal, consunção, entre outros novos conceitos.

Nesse processo, o acadêmico transforma significados lógicos e potencialmente significativos em significados psicológicos, à medida que os conteúdos conceituais são incorporados à sua estrutura cognitiva, em uma conexão não literal, ampliando o seu universo de significados incidentes sobre a conduta penalmente relevante e a sua sanção correlata.

12 Ausubel, David P. The Psychology of Meaningful Verbal Learning. New York: Grune \& Stratton, 1963 apud. MOREIRA, Marco Antônio. Aprendizagem significativa: a teoria e textos complementares. p. 15

13 MOREIRA, Marco Antônio. Aprendizagem significativa: a teoria e textos complementares. p. 18. 
Os mapas são diagramas de significados que representam relações significativas entre conceitos na forma de proposições, constituídas com base na relação entre dois ou mais conceitos unidos por conectivos para compor uma unidade semântica, com a finalidade de explorar as relações existentes entre as ideias, definir similitudes e diferenças operativas para reconciliar as discrepâncias aparentes ou reais ${ }^{14}$. Têm como principal objetivo evidenciar os significados imputados aos conceitos e às relações que se estabelecem entre eles no quadro conceitual de um campo do conhecimento, ou do conteúdo de uma disciplina como o Direito Penal.

Conceitos como norma penal, crime, conduta típica, dolo, culpa, preterdolo, legítima defesa e imputabilidade são passíveis de representação gráfica, traduzidos em mapas conceituais. Com a adoção desse recurso, poder-se-á criar representações gráficas das conexões significativas entre conceitos logicamente ordenados para serem operadas tecnicamente, dimensionando as limitações teóricas e operativas da dogmática jurídica, por meio da análise de situações fáticas.

A adoção desse instrumento permite a construção de estruturas mentais, que proporcionam visibilidade à lógica que ordena o Direito Penal, as quais são geralmente obscurecidas nos manuais, tais como a relação existente entre o dolo direto e os conceitos de crime impossível, tentativa, erro sobre a pessoa, erro na execução, erro sobre nexo causal e o Princípio da Consunção.

O mapa conceitual configura-se como um recurso flexível, podendo ser usado em diversas situações para diferentes finalidades, tais como recurso de aprendizagem, meio de avaliação ${ }^{15}$ e organizador prévio. No presente artigo, o mapa será empregado fundamentalmente como organizador prévio, cuja finalidade é compor uma ponte cognitiva entre o conhecimento existente na estrutura cognitiva do aprendiz e o conhecimento contido no material de aprendizagem, com a finalidade de explicitar relações conceituais, por vezes 14 NOVAK, Joseph D., GOWIN, D. Bob. Aprender a aprender. 2. ed. Lisboa: Plátano Edições Técnicas, 1999. p. 31. Disponível em: www.ir.nmu.org.ua. Acesso em: setembro de 2014.

15 SOUZA, Nadia Aparecida de; Boruchovitch, Evely. Mapas conceituais: estratégia de ensino/ aprendizagem e ferramenta avaliativa. Educação em Revista, Belo Horizonte, vol.26, no.3, p. 195-217. Dez/2010. Disponível em: www.scielo.br. Acesso em: fevereiro de 2015. 
imperceptíveis ao aprendiz, com base nos manuais tradicionalmente empregados no ensino do Direito Penal.

\section{CONDUTA TÍPICA: UMA EXPECTATIVA COMPORTAMENTAL ESTÁVEL}

Em todas as sociedades, os indivíduos interagem em um ambiente cuja estabilidade das expectativas comportamentais generalizadas não é possível sem a vigência de sistemas normativos relativamente estáveis, compartilhados entre os indivíduos, tais como os sistemas de normas morais, normas religiosas e o de normas jurídicas. Isto porque as relações constituídas entre os indivíduos não podem ser fundadas na incerteza quanto ao comportamento pessoal ou institucional ${ }^{16}$.

Na concepção de Durkheim ${ }^{17}$, o Direito constitui o elemento fundamental do processo de regulamentação da vida social na sociedade urbano-industrial à medida que a norma jurídica se configura como o instrumento institucionalizado mais importante de controle social, visto dispor de força coercitiva para impor seu comando normativo aos indivíduos, por meio das instituições socialmente criadas para esse fim.

Diversamente, as demais normas sociais, emanadas das interações sociais ocorridas na família, na igreja, na fábrica, na escola, entre outros espaços sociais, geram para o indivíduo um conjunto de expectativas sociais, dotadas de força coercitiva indireta, cuja inobservância gera sanções com forma de manifestação variada, tais como o constrangimento sutil e o sentimento de culpa.

Embora Durkheim ${ }^{18}$ enfatize a importância do direito positivo para o ordenamento da vida social, não deixa de fazer alusão à interdependência entre as normas jurídicas e as demais normas sociais para o fortalecimento da solidariedade social, posto ser inegável a inter-relação entre o fenômeno jurídico e os demais fenômenos culturais. Pois a variedade de normas sociais desvela

16 ROXIN, Claus. Estudos de Direito Penal. Trad. Luis Greco. Rio de Janeiro: Renovar, 2012. p. 33.

17 DURKHEIM, Emile. A Divisão do Trabalho Social. Trad. de Eduardo Brandão. São Paulo: Martins Fontes,1999. p. 75.

18 DURKHEIM, Emile. As Regras do Método sociológico. Trad. Pietro Nassetti. São Paulo: Martin Claret, 2004. p. 86. 
um feixe aberto de expectativas comportamentais, constituídas nas menores unidades do sistema social, com vasta força coercitiva e difusa que repercute nas relações sociais.

Consoante esse autor, o Direito é o símbolo mais expressivo da solidariedade social por refletir uma parte significativa da vida social, à qual se agregam tradição, costumes e valores. Assim, a prática de um crime realiza-se como uma conduta que ofende à sociedade, ensejando para o transgressor a aplicação de uma sanção repressiva, proporcional ao juízo de reprovação e à agressão aos bens jurídicos tutelados pela norma penal. Para esse autor, a sanção penal não constitui um ato de crueldade, mas um mecanismo de proteção do sistema social, uma vez que a sanção derivada do Direito Penal se destina à afirmação e à proteção dos valores e dos sentimentos coletivos (bens jurídicos), transcendendo, portanto, o indivíduo.

Nesse contexto, a necessidade de controlar a incerteza do jogo interacional entre os indivíduos impele o Estado a constituir códigos normativos estruturantes das relações jurídico-penais, cujas normas instituem comandos proibitivos e permissivos para estabilizar as expectativas de condutas. No processo de criação das normas penais, o Estado deve obediência ao princípio da legalidade, da anterioridade e da taxatividade, dispostos nos artigos $5^{\circ}$, XXXIX, da Constituição Federal (CF), e 10 ${ }^{\circ}$ do Código Penal (CP).

As normas penais tipificam, abstratamente, modelos de condutas penalmente relevantes que vinculam todos os seus destinatários, tornando-se obrigatórios, visto que são instituídos com a finalidade de regulamentar a vida em sociedade, bem como proteger os bens jurídicos penais e os valores socialmente instituídos ${ }^{19}$. Assim, cotidianamente o indivíduo se depara com as normas penais, constituídas como referentes estáveis para orientá-lo no seu modo de agir, possibilitando-lhe a escolha entre a conduta típica e a conduta atípica. E é justamente a escolha livre e consciente pela prática da conduta típica que aciona a persecução penal e o exercício do poder punitivo do Estado, visto que a conduta atípica é penalmente irrelevante, portanto, incapaz de produzir qualquer consequência jurídica, conforme se observa no Mapa 1.

19 ROXIN, Claus. Estudos de Direito Penal. Rio de Janeiro: Renovar, 2012. p. 33. 


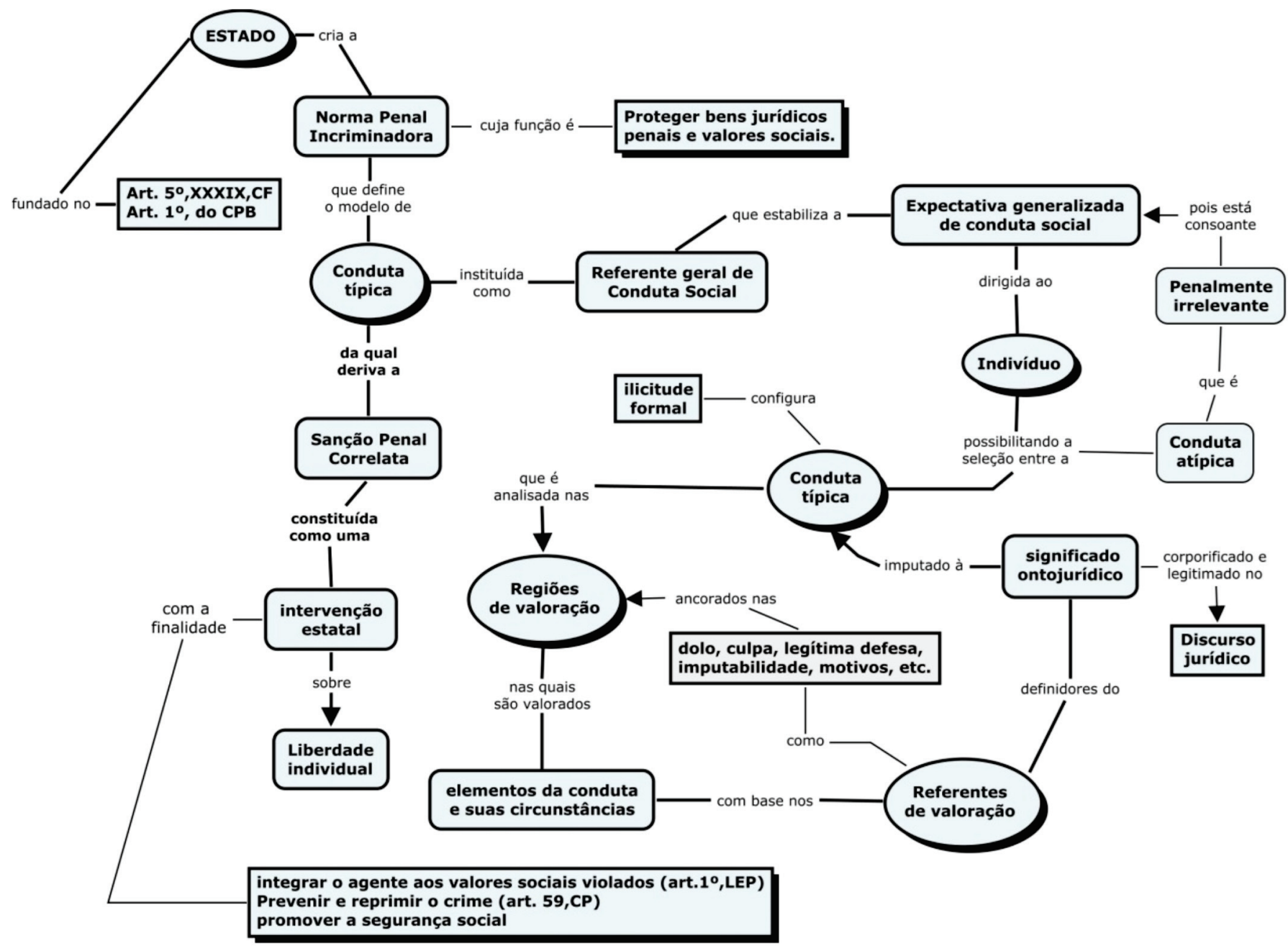

Mapa 1 - Norma penal e estabilidade das expectativas de conduta

Da leitura do Mapa 1, pode-se deduzir as seguintes proposições:

1) com base nos artigos $5^{\circ}, \mathrm{XXXIX}$, da $C F$, e $1^{\circ}$, do $C P$, o Estado cria a norma penal incriminadora, que define o modelo de conduta típica, cuja função é proteger bens jurídicos;

2) a conduta típica é instituída como referente geral de conduta social, que produz a estabilidade da expectativa generalizada de conduta social, dirigida ao indivíduo, possibilitando-Ihe a seleção entre a conduta típica e a conduta atípica (irrelevante do ponto de vista penal);

3) a seleção da conduta típica configura-se tão somente como indicativo de ilicitude (ilicitude formal), não sendo suficiente para caracterizar o crime. Deve-se observar que a norma penal oferece apenas os elementos mínimos necessários ao reconhecimento da conduta ilícita e imputável ao agente que a pratica, mas a 
imputação se realiza como resultado da valoração jurídico-penal de uma conduta atribuível a um agente, que não se esgota na mera descrição de um tipo penal, disposto em uma norma penal vigente, tais como "matar alguém", descrita no art. 121, do CP, e 302, do Código de Trânsito Brasileiro (CTB);

4) a conduta típica é analisada nas regiões de valoração ontojurídica, na quais são valorados os seus elementos objetivos, subjetivos e normativos, bem como suas circunstâncias, com base nos referentes de valoração nelas ancorados, referentes que definem o significado ontojurídico imputado à conduta típica, corporificado e legitimado no discurso jurídico penal;

5) da conduta típica deriva uma sanção correlata, constituída como uma intervenção do Estado sobre a liberdade individual, com finalidade de integrar harmonicamente o agente aos valores sociais violados, consoante disposição do art. $1^{\circ}$ da Lei de Execução Penal (LEP), prevenir e reprimir o crime, consoante o art. 59, do CP, bem como prover a segurança social.

Em perspectiva finalista, a conduta é a fase final de um processo ativo que começa no campo intelectual e termina na esfera muscular com a exteriorização e realização da vontade. Refere-se ao modo de ser, de se comportar, consoante às expectativas de condutas estabilizadas, por meio da norma penal e da interconexão subjetiva constituída entre os agentes ${ }^{20}$.

Na forma como ela imediatamente se apresenta, subjazem elementos internos e externos ao agente, consubstanciados em referentes de valoração que podem ser sistematizados em regiões para orientar a sua valoração ontojurídica. Daí deriva o seu caráter ontológico, combinado com os ditames jurídicos de regramento social embutidos nos referentes de valoração. Partindo-se desse pressuposto, observa-se que, quando o indivíduo pratica uma conduta típica, a exemplo de "matar alguém", referentes de valoração ontojurídica, como dolo, culpa, tentativa, legítima defesa, imputabilidade, exigibilidade de conduta diversa, personalidade, motivos, reincidência e prescrição, deixam de ter existência ideal para, no plano da concreção, delinear os contornos do significado penal a ela imputado em regiões de valoração específicas, relacionadas à definição do crime ou à fixação da pena. 20 WELZEL, Hans. O novo sistema jurídico-penal: uma introdução à doutrina da ação finalista. 2. ed. Trad. Luiz Regis Prado. São Paulo: Revista dos Tribunais, 2010. p. 29. 
Nesse sentido, os referentes de valoração têm sua função analítica vinculada à definição dos contornos jurídicos da conduta praticada pelo agente e sua sanção correlata. Isso resulta em uma compreensão estreitamente vinculada e mutuamente necessária entre os referentes de valoração e a conduta, uma vez que são concebidas como unidades elementares da lógica que ordena a valoração concreta da conduta em regiões específicas. Portanto, a integração sistemática dos referentes de valoração em regiões possibilita a constituição de uma regularidade que é alcançada pela análise regionalizada da conduta.

Concretamente, a conduta é marcada pela singularidade, cuja significação penal depende de sua materialidade e valoração desenvolvidas nos caminhos da administração da justiça criminal pelos órgãos que possuem função valorativa. Dessa forma, o crime se materializa na valoração da conduta, cujo significado penal é construído com base na dedução dos sentidos depositados nos referentes de valoração ancorados na instância singular de cada uma das três regiões que o compõem, a saber: a tipicidade, a ilicitude e a culpabilidade.

Assim, por exemplo, ao valorar a tipicidade da conduta, não se deve separar os elementos de imputação objetiva (conduta típica, resultado e nexo causal) dos de elementos de imputação subjetiva (dolo ou culpa), pois é articulação entre eles que confere sentido e relevância penal à conduta valorada ${ }^{21}$. Essa valoração transcende o conteúdo naturalista do nexo causal, expresso no art. 13, do CP, posto que o Direito Penal define diferentes graus de reprovação e imputação para uma mesma conduta e a norma penal oferece apenas os elementos descritivos necessários ao reconhecimento da ilicitude formal22. Em suma, a imputação resulta da valoração de uma conduta atribuível a um agente que não se esgota na mera descrição de um tipo penal, disposto em uma norma penal vigente.

\section{AS REGIÕES DE VALORAÇÃO ONTOJURÍDICA}

Conforme se referiu, a região de valoração ontojurídica configura-se como um espaço conjuntural no qual se ancoram e se ordenam os referentes conceituais 21 WELZEL, Hans. O novo sistema jurídico-penal: uma introdução à doutrina da ação finalista. 2. ed. p. 32.

22 BITENCOURT, Cezar Roberto. Manual de direito penal: parte geral. 6. ed. São Paulo: Saraiva, 2012, vol. 1.p. 384. 
empregados na valoração dos elementos objetivos e subjetivos que compõem a conduta típica, suas circunstâncias e sanção correlata, conformando um padrão procedimental de valoração único, que exclui todos os demais elementos e referentes que não Ihe fazem sentido.

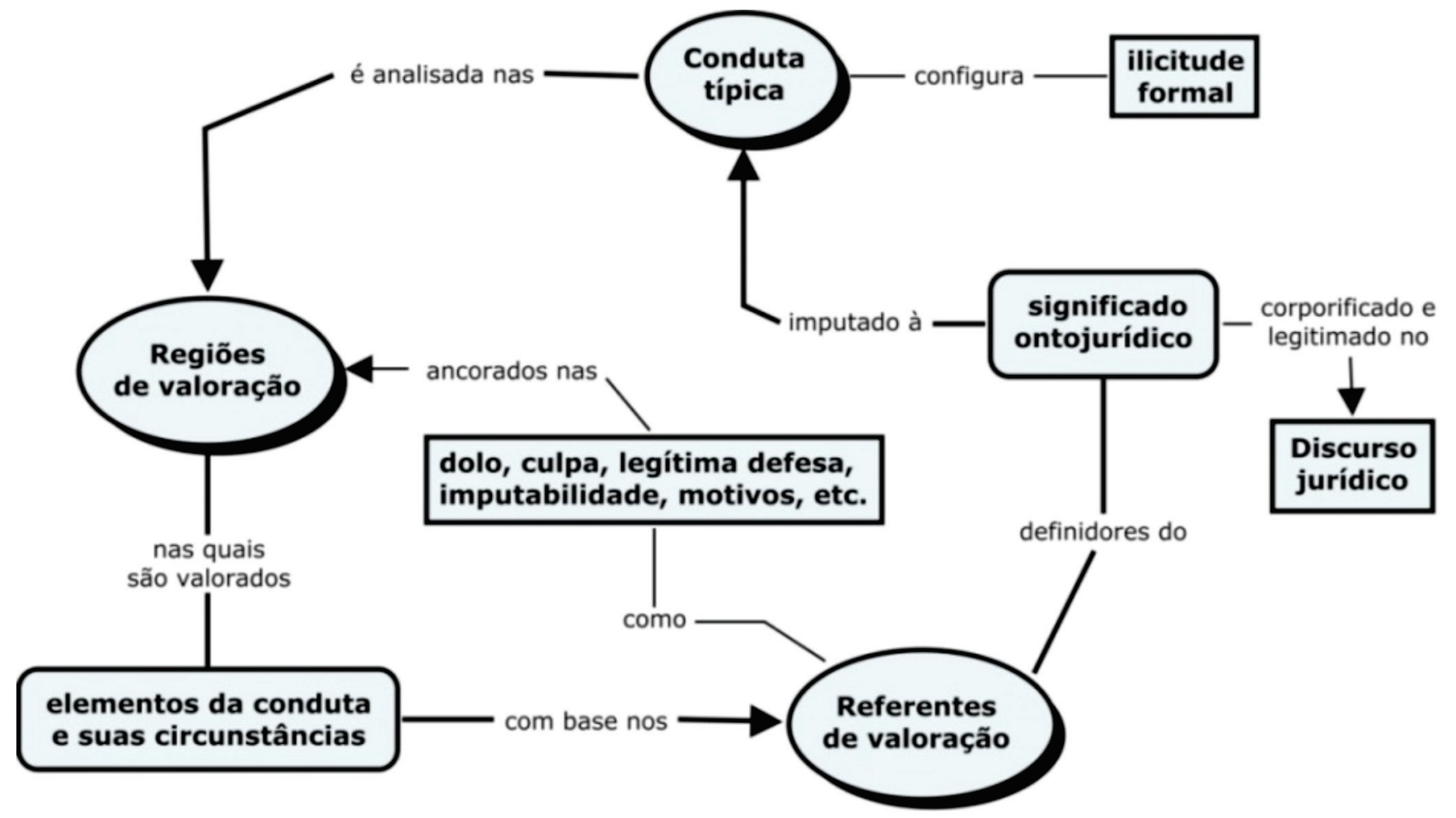

Mapa 2 - Regiões de valoração ontojurídica

Partindo-se desse pressuposto, a valoração da conduta se desenvolve de forma regionalizada, com base em referentes estáveis e não arbitrários, em um processo cujo resultado é o explícito delineamento das diferenças e das similaridades entre as regiões e os referentes de valoração a elas relacionados. Nesse sentido, os conceitos adquirem significados progressivamente diferenciados, que podem ser reconhecidos, relacionados e reorganizados de forma integrativa, por meio de um processo de interação e ancoragem.

Com a adoção desse procedimento, acredita-se ser possível recortar a conduta humana e ordená-la racionalmente em regiões de conhecimento, tornando-a compreensível no campo jurídico-penal e, paralelamente, construir e mapear espaços conjunturais limitativos nos quais as condutas concretas possam ser contrastadas e classificadas com base em referentes de valoração racionalmente construídos. 
Conforme se ilustra no Mapa 3, tendo como base o Código Penal, em princípio pode-se identificar oito regiões de valoração. A tipicidade, a Ilicitude e a culpabilidade são as regiões cujos referentes de valoração estão relacionados à constituição do crime. Já a fixação da pena, concurso de crimes, concurso de agentes, conflito geral de normas e extinção da punibilidade são regiões cujos referentes de valoração estão relacionados à definição da pena. A tipicidade é o ponto de partida para valoração da conduta ${ }^{23}$.

Conforme se observa no Mapa 3, o conceito de crime possui três regiões de valoração intimamente articuladas, cada uma com seus próprios referentes de valoração da conduta, os quais compõem um todo conceitual. É com base na valoração desses referentes que a conduta deverá ser considerada típica ou atípica, lícita ou Ilícita, culpável ou não culpável. Isto é, configura ou não configura crime. Nesse sentido, a conduta será a valorada primeiramente na tipicidade. Inexistindo conduta típica, dolo ou culpa e nexo causal entre a conduta e o resultado, encerra-se a operação e a conduta será atípica. Todavia, se houver tipicidade, a conduta será deslocada para a Ilicitude.

Para definir se a conduta é lícita ou ilícita, a conduta tipificada na norma penal deve ser valorada com base nos referentes relacionados ao ordenamento jurídico pela natureza do seu mandamento proibitivo. Dessa forma, realizase, paralelamente, a valoração da conduta frente às normas que proíbem e às que justificam sua realização. Assim, se a conduta é típica, mas sobre ela incide uma norma penal permissiva justificante, tais como legítima defesa, estado de necessidade, exercício regular do direito, ou estrito cumprimento do dever legal, encerra-se a operação, pois se está ante a hipótese da excludente de ilicitude. Todavia, se considerada ilícita, a conduta será deslocada para a culpabilidade.

A culpabilidade é a região na qual a conduta é valorada com base nos referentes relacionados às normas penais exculpantes, tais como imputabilidade, consciência potencial da ilicitude e exigibilidade de conduta diversa. Assim, se sobre a conduta incidir uma norma penal dirimente ou exculpante, tais como a 23 Embora se tenha identificado, em princípio, oitos regiões, neste trabalho será feita alusão apenas às referentes à constituição do conceito analítico de crime, visto que as demais serão objeto de outro trabalho. 
coação moral irresistível, a obediência hierárquica ou as escusas absolutórias, encerra-se a operação, pois estará configurada a excludente de culpabilidade inexistindo, portanto, o crime. Todavia, se considerada culpável, encerra-se a operação e o conceito de crime ganha vida no plano da concreção.

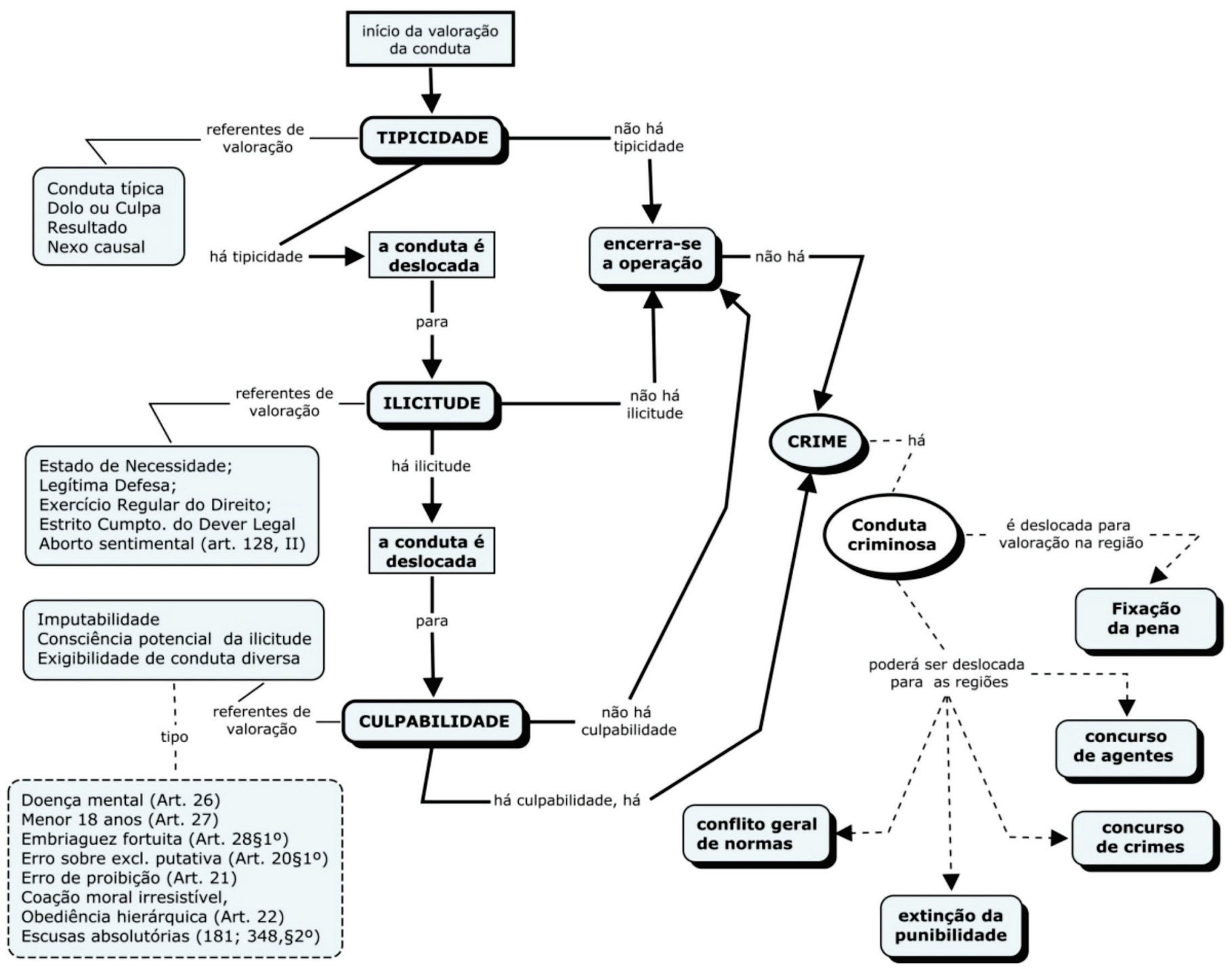

Mapa 3 - Regiões de valoração ontojurídica da conduta

Havendo crime, a conduta será deslocada para a fixação da pena. Nessa região a conduta será valorada com base nos referentes relacionados ao sistema trifásico de fixação da pena, inscritos nas circunstâncias judiciais, nas circunstâncias legais e nas causas de aumento ou diminuição da pena.

O deslocamento da conduta entre as regiões depende do caso concreto em exame. Assim, por exemplo, se João mata, dolosamente, José sem a ajuda de qualquer outra pessoa, não há concurso de agentes. Portanto, a conduta praticada por João não será deslocada para a região do concurso de agentes, na qual os 
referentes de valoração são relativos à coautoria, à participação, à cooperação dolosamente distinta, ao domínio dos fatos e à autoria colateral.

Nessa perspectiva, o deslocamento da conduta entre as regiões configura-se como uma operação lógica que proporciona maior visibilidade à sua valoração racional. Nessa operação, o que se recorta não é a conduta em si, mas as regiões nas quais ela é inserida e valorada. Dessa forma, a conduta "matar alguém" não será desconstituída ao ser deslocada da tipicidade para a ilicitude e desta para a culpabilidade. O que muda são os referentes de valoração ancorados em cada região e o sentido que a conduta assume em cada uma delas.

Partindo-se desse pressuposto, a valoração referencial regionalizada constitui um recurso empregado para realizar a imputação jurídico-penal da conduta, suas circunstâncias e a sanção penal correlata. Isso porque o horizonte das possibilidades de valoração dado em cada região está na unidade de sua diferença com as outras regiões. Portanto, a imputação resulta da distinção da valoração da conduta que deve ser empreendida nas diferentes regiões, tais como ocorre na tipicidade, ilicitude, culpabilidade, cujos referentes de valoração relacionamse à consubstanciação do crime.

Nessa operação não há propriamente hierarquia na diferenciação funcional ou operativa entre as regiões, ou uma região guia identificada como central que determina as demais, pois a centralidade encontra-se na conduta que passa por um deslocamento contínuo, iniciado com a valoração da tipicidade e encerrado com a fixação da pena na sentença condenatória ou com absolvição na sentença absolutória.

A constituição das regiões e a definição de seus referentes de valoração não configuram um isolamento, mas uma função técnico-operativa que permite integrar conceitualmente o conceito de crime e sua sanção correlata, por meio de uma abertura cognitiva, bem como construir e reconstruir a comunicação constante entre as regiões mediante o deslocamento da conduta.

Ao se definir e se ancorar os referentes de valoração em cada região, tem-se condições de definir as operações de valoração ontojurídica, determinando os 
elementos da conduta que pertencem a cada região. Assim, esses elementos poderão ser incorporados, deslocados ou descartados para resguardar a relativa autonomia regional, visto que eles só fazem sentido quando valorados na região capaz de imputar significado jurídico à conduta.

Nesse sentido, pode-se imaginar as seguintes hipóteses, considerando-se as "consequências da conduta" praticada pelo agente, como referente de valoração pertencente à região da Fixação da Pena, prevista no art. 59, do CP:

1) Pedro disparou dois tiros contra Carlos, usando um revólver calibre 38, com a finalidade de matá-lo (conduta dolosa). Ocorre, porém, que só um dos projéteis atingiu a vítima na coluna cervical, deixando-a tetraplégica (consequência da conduta);

2) João disparou dois tiros contra José, usando um revólver calibre 38, com a finalidade de matá-lo (conduta dolosa), porém nenhum dos projéteis atingiu a vítima, que saiu ilesa do atentado (consequência da conduta).

Nessas hipóteses, imagina-se que, após valorar a tipicidade, a ilicitude e a culpabilidade, as condutas praticadas por Pedro e João foram tipificadas como homicídio simples, em sua forma tentada, conforme disposição do art. $121 \mathrm{c} / \mathrm{c}$ 14 , II, do CP. Nesses casos, as consequências das condutas não são valoradas nas regiões que definem o crime em sua forma tentada ou consumada (Tipicidade). Todavia, quando a conduta for deslocada da culpabilidade para a região na qual se processa fixação da pena, as consequências das condutas (referente de valoração) praticadas por Pedro e João serão valoradas e se refletirão no quantum de pena que será aplicado a ambos, consoante disposição do art. 59, CP. Ou seja, embora irrelevante para efeito de valoração na Tipicidade, Ilicitude e Culpabilidade, as "consequências da conduta" constituem referentes de valoração significativos quando processados na região da fixação da pena.

No mesmo sentido, pode-se ressaltar que a conduta conscientemente dirigida à realização de um tipo penal determinado pressupõe o conhecimento atualizado de todos os seus aspectos, tais como consciência da relação conectiva entre a conduta e o resultado, consciência da idoneidade dos meios necessários à sua realização, bem como a representação dos resultados produzidos que são 
valorados na tipicidade. Porém essa consciência que compõe a conduta dolosa é desprovida de qualquer juízo valorativo incidente sobre a ilicitude do fato, expresso na "Consciência Potencial da Ilicitude". Assim, a Consciência Potencial da Ilicitude da conduta, que é descartada como referente de valoração na tipicidade, é valorada na região da culpabilidade para constituir-se como referente de valoração próprio dessa região.

Portanto, o deslocamento da conduta configura-se como uma operação que dá maior visibilidade à integração conceitual do crime e da sua sanção correlata, à medida que em cada região são selecionados e codificados, tão somente, os elementos que fazem sentido à sua valoração e à imputação. Nessa operação, o que se recorta não é a conduta em si, mas as regiões nas quais ela é inserida e valorada.

Assim, na caracterização do crime de homicídio, bem como na definição de sua sanção correlata, a conduta "matar alguém", tipificada no art. 121, do CP, não deixa de ser "matar alguém" quando é deslocada da tipicidade para a ilicitude e desta para a culpabilidade. O mesmo corre quando ela é deslocada para a região onde são processados os referentes de valoração relativos à fixação da pena, ao concurso de agente, ao concurso de crimes, ao conflito geral de normas e à extinção da punibilidade. Ou seja, continua "matar alguém" independentemente da pena de reclusão aplicada que varia entre 06 (seis) e 20 (vinte) anos. O que muda são os referentes de valoração ancorados em cada região e o significado imputativo impresso à conduta em cada uma delas.

Com a adoção da valoração regionalizada, é possível dar maior visibilidade à imputação do significado jurídico impresso à conduta e à sua sanção correlata. Isto porque as operações de valoração realizadas em uma região se abrem às outras para completá-las. É fundado nesse pressuposto que, ao valorar a conduta, deve-se buscar na tipicidade os sentidos do típico, na ilicitude, os sentidos do ilícito e na culpabilidade, os sentidos do culpável.

\section{OS REFERENTES DE VALORAÇÃO ONTOJURÍDICA}

Os referentes de valoração ontojurídica configuram-se como conceitos ou categorias abstratas, tais como dolo, culpa, preterdolo, erro de tipo, legítima 
defesa, imputabilidade, consciência potencial da ilicitude, personalidade, motivos e prescrição, que podem expressar aspectos particulares de uma dada conduta. Eles emergem, então, como meios que servem para traduzir um conjunto específico de relações que se pretende compreender, cujos contornos jurídicos são definidos como universalidade.

Esses referentes têm sua função analítica vinculada à definição dos contornos jurídicos da conduta praticada pelo agente e sua sanção correlata. Isso resulta em uma compreensão estreitamente vinculada e mutuamente necessária entre os referentes de valoração e a conduta, uma vez que são concebidas como unidades elementares da lógica que ordena a valoração concreta da conduta em regiões específicas. Assim, a integração sistemática dos referentes de valoração em regiões possibilita a constituição de uma regularidade que é alcançada pela análise regionalizada da conduta.

Esses conceitos, todavia, cristalizam-se no cenário prático de sua existência tendo como base a conduta humana praticada em um determinado caso concreto. Assim, eles não se reduzem à mera abstração, ao contrário, influenciam a construção real da conduta criminosa e sua sanção correlata, pois traduzem a realidade do ser e das relações entre seres, dimensão que não pode ser desconsiderada na valoração da conduta penalmente relevante.

Nesse sentido, ao abordar a relação entre normativismo e dados empíricos, Roxin ${ }^{24}$ propõe uma dogmática plena de dados empíricos que não se reduz a meras estruturas lógico-reais um tanto abstratas, uma vez que não se excluem mutuamente, mas, ao contrário, complementam-se para promover a abordagem da conduta penalmente relevante.

Os referentes de valoração delimitam as fronteiras de cada região, pois configuram as unidades da diferença que permitem valorar somente os elementos da conduta identificados no âmbito de cada região, limitando racionalmente as possibilidades de imputação. Eles são empregados nas operações recursivas que diferenciam funcional e clausuralmente as regiões, proporcionando a equivalência 24 ROXIN, Claus. O conceito de bem jurídico como padrão crítico da norma penal posto à prova. Trad. Susana Aires de Sousa. Revista Portuguesa de Ciência Criminal, Coimbra, Ano 23, n. ${ }^{1}$ (janeiro-março 2013). p. 7-43. 
necessária para que se possa minimizar a margem de discricionariedade do julgador, ao mesmo tempo em que preservam a identidade regional quando contraposta a outras regiões. Dessa forma, exsurge as fronteiras limites das regiões de valoração, dando visibilidade ontojurídica ao conceito analítico de crime e à fundamentação da sanção correlata.

Entende-se, então, que os referentes de valoração atuam como força configurante não só da conduta criminosa, mas também da fixação da sanção correlata e demais consequências jurídicas, tais como extinção do direito de punir, corporificado na prescrição. Isto porque sem essa base de modelagem previamente construída, a imputação da conduta não seria possível de ser executada, senão com base em presunções pessoais ou na discricionariedade do julgador, o que seria um risco à segurança jurídica.

É a partir da aplicação prática propriamente dita que esses referentes abstratos ganham vida no plano ontológico. Dessa forma, a conduta humana é o fio condutor que no plano da concreção confere existência às regiões e seus referentes de valoração, razão pela qual a valoração se realiza como uma valoração ontojurídica, pois não é razoável criar designações de referência valorativa da conduta humana despida de seus elementos ontológicos e jurídicos.

O deslocamento da conduta entre as regiões permite conhecê-la sistematicamente em suas dimensões psicológica, normativa e naturalística. Cabe, porém, observar que, embora seja possível formular significações abstratas, não há como definir sua devida aplicabilidade até que se tenha concretamente o caso para análise. Conjecturar prováveis significados imputados à conduta com fundamento em elementos meramente formais não conduz a uma abordagem razoável dos eventos que envolvem a prática de um crime, visto que a conduta criminosa possui elementos circunstanciais necessários à sua existência que devem ser valorados para dar solução ao caso concreto.

Na valoração da conduta concretamente analisada, os referentes de valoração são individualizados e tornam-se concretos, uma vez que o significado imputado 
a esta é construído com base na sua movimentação entre as regiões. Dessa forma, os referentes passam de seu estágio estático para os domínios dinâmicos do plano ontológico, suplantando-se o sentido abstrato e apriorístico de sua criação que pode ser atualizado na sua aplicação prática. É nesse processo que o significado imputado à conduta deve ser vertido na atividade aplicativa dos referentes de valoração.

\section{O DOLO DIRETO COMO ORGANIZADOR PRÉVIO}

Nos noticiários nacionais, ou locais, é comum ouvir os jornalistas se referirem ao conceito de dolo, ou à culpa nos seguintes termos: "O acusado responderá por homicídio doloso, ou seja, quando tem a intenção de matar". "O acusado responderá por homicídio culposo, ou seja, quando não tem a intenção de matar". Todavia, é equivocado conceber o dolo em oposição à culpa, tendo como referência exclusiva a "intenção" de alcançar o resultado.

Indubitavelmente, a ação conscientemente dirigida à realização do tipo penal determinado, tais como matar alguém, subtrair coisa alheia móvel para si ou para outrem, portar arma de fogo é necessária à constituição do dolo ${ }^{25}$. Todavia, esse elemento por si só não é suficiente para configurá-lo, pois, conforme referido, o Direito Penal prescreve diferentes juízos de reprovação e imputação para uma mesma conduta.

Consoante Welzel ${ }^{26}$, os homens agem ou deixam de agir conscientemente orientados para fins determinados e a satisfação da vontade. Assim, a conduta dolosa é concebida como ação ou omissão ontologicamente ordenada, dotada de sentido jurídico-penal que se realiza como um processo de consciência dos efeitos causais da ação finalista. Portanto, a vontade está na base da conduta dolosa, constituindo-se como elemento psicológico integrado a ela, visto que ontologicamente não há como separá-la de seu elemento volitivo e finalístico,

25 Cabe ressaltar que neste artigo se abordará, tão somente, a conduta dolosa, modalidade dolo direto, em razão do objetivo proposto. A conduta culposa, preterdolosa e a dolosa, modalidade dolo eventual, serão abordadas em outro artigo com recurso dos mapas conceituais.

26 WELZEL, Hans. O novo sistema jurídico-penal: uma introdução à doutrina da ação finalista. 2. ed. p. 33/34. 
razão pela qual se sustenta que a tipicidade não se esgota na simples conexão causal entre a conduta e o resultado. Isto é, a valoração da conduta transcende o conteúdo naturalista do nexo causal, expresso no art. 13, do CP.

Nesse sentido, a valoração da conexão de sentidos inscritos na conduta provida de consciência e vontade dirigida à produção de um tipo penal determinado, no contexto em que é praticada, configura o meio ideal para definir a conduta típica, em sua forma consumada ou tentada, bem como para dimensionar o alcance da tipicidade em oposição à excludente de tipicidade.

Para Welzel27, a vontade integra-se à conduta e a valoração de seu conteúdo estende-seaosmeiosempregadospeloagentepararealizarotipopenaldeterminado, bem como às condutas concomitantes a eles integradas e à propriedade material do objeto descrito na norma penal. Partindo-se desse pressuposto, a diferença ontológica entre a Tentativa, prevista no art. 14, II, do CP, e o Crime Impossível, previsto no art. 17, do CP, é tecnicamente resolvida na estrutura conceitual do dolo, centrada na valoração da (in)adequação dos meios empregados e na (im) propriedade material do objeto do tipo penal, conforme se observa no Mapa 5.

Os crimes dolosos nas modalidades consumada e tentada apresentam diferenças tão somente de forma e não de conteúdo em suas estruturas conceituais, visto que na tentativa o resultado não ocorre por circunstâncias alheias à vontade do agente, conforme se demonstrará nos Mapas 4 e 5.

Para ilustrar o Mapa 4, imagine-se que Lucas alugou um revólver, calibre 38, com a finalidade específica de matar João e, após encontrá-lo, disparou dois tiros contra a cabeça do desafeto com a vontade conscientemente dirigida à finalidade de matá-lo, vontade que se realizou com a morte da vítima. Nessa hipótese, a conduta é dolosa e o crime é consumado. Dessa forma, a sua valoração é bem mais simples, pois, conforme se observa no Mapa 4, em sua estrutura, a conduta dolosa apresenta as seguintes proposições:

1) o agente pratica a conduta agindo com consciência da relação conectiva entre a conduta e o resultado descrito em um tipo penal determinado, tornando-o objetivamente previsível;

27 WELZEL, Hans. O novo sistema jurídico-penal: uma introdução à doutrina da ação finalista. 2. ed. p. 33/34. 
2) há nexo causal entre a conduta e o resultado;

3) o agente pratica a conduta agindo com a vontade conscientemente dirigida à finalidade de realizar um tipo penal determinado, corporificado em um resultado, tornando-o subjetivamente previsível;

4) a vontade conscientemente dirigida à realização do tipo penal determinado produz um nexo finalista entre a conduta e o tipo penal;

5) o conteúdo da vontade é a base valorativa que define o tipo penal em sua forma tentada, ou consumada;

6) o conteúdo da vontade estende-se aos meios empregados na realização do tipo penal, ao seu objeto material, bem como às condutas concomitantes integradas aos meios empregados na realização do tipo penal.

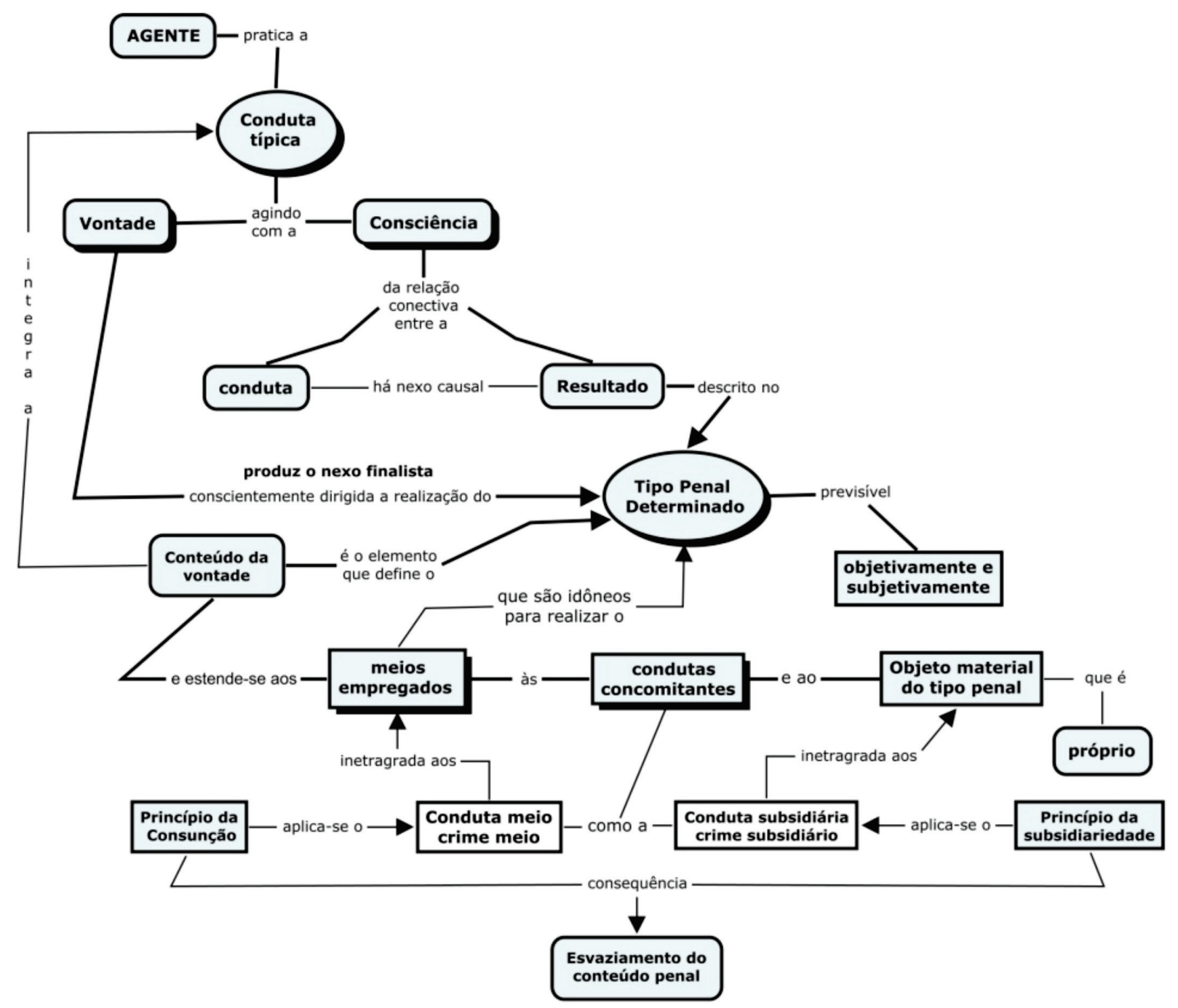

Mapa 4 - Conduta dolosa - crimes materiais consumados 


\section{DOLO DIRETO, TENTATIVA E CRIME IMPOSSÍVEL}

Consoante o artigo 14, II, do CP, a tentativa, em sentido estrito, configurase quando iniciada a execução, o crime não se consuma por circunstâncias alheias à vontade do agente. Por sua vez, o artigo 17 , do $C P$, estatui que não se pune a tentativa quando, por ineficácia absoluta do meio ou por absoluta impropriedade do objeto material, é impossível consumar-se o crime. É muito comum haver dúvidas na diferenciação entre a tentativa e o crime impossível, visto que são espécies do mesmo gênero (tentativa, em sentido lato), cujo tipo penal determinado não se consuma por circunstâncias alheias à vontade do agente.

O artigo 14, II, do CP, constitui uma norma extensiva, que ao ampliar o alcance epistêmico de um tipo penal incriminador, incorpora a ele situações fáticas que não estão expressamente tipificadas. Sem esse dispositivo seria inadmissível, por exemplo, a imputação de um homicídio, se a morte da vítima não se consumasse, por afronta ao princípio da legalidade.

Embora o artigo 18, I, do CP, faça referência ao resultado, concebendo-o como lesão ao bem jurídico tutelado, ele é irrelevante para a configuração do dolo, pois conforme se observa na sua estrutura conceitual, o tipo penal é definido com base na valoração do conteúdo inscrito na vontade do agente que pratica a conduta. Logo, o resultado é importante tão somente para definir o crime em sua forma tentada ou consumada ${ }^{28}$.

Partindo-se desse pressuposto, a diferença ontológica entre a Tentativa e o Crime Impossível é tecnicamente resolvida na estrutura conceitual do dolo, centrada na valoração da adequação ou da inadequação dos meios empregados e na propriedade ou impropriedade material do objeto do tipo penal.

28 Essa distorção foi corrigida no projeto do Novo Código Penal, com a seguinte disposição:

\section{Dolo e culpa}

Art. 18. Diz-se o crime:

I - doloso, quando o agente quis realizar o tipo penal ou assumiu o risco de realizá-lo, consentindo ou aceitando de modo indiferente o resultado. 
Teoricamente, não há diferença substancial no conceito de dolo empregado para valorar a conduta típica, seja ela consumada ou tentada. Todavia, a forma de operacionalizá-lo apresenta leve variação nos componentes de sua estrutura conceitual. Isto porque, diversamente do crime consumado que apresenta conduta, resultado e nexo causal, no crime tentado não há consumação e, consequentemente, não há resultado ou nexo causal.

Conforme se observa no Mapa 5, quando o resultado não ocorre por circunstâncias alheias à vontade do agente, abrem-se duas possiblidades:

1) a conduta típica configura o crime em sua forma tentada, consoante disposição do Art. 14, I, do CP;

2) a conduta configura o crime impossível, consoante o disposto no art. 17, do CP.

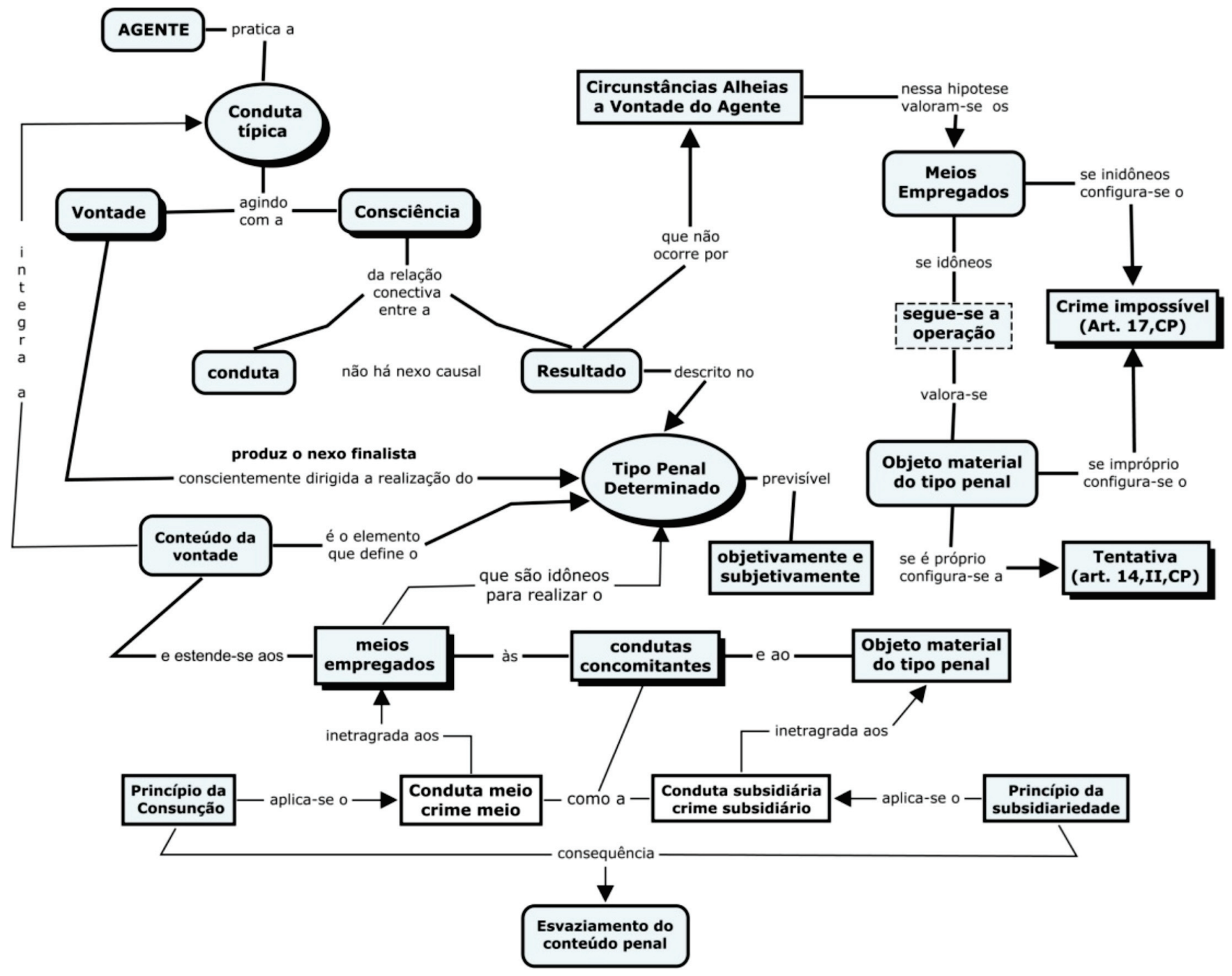

Mapa 5 - Conduta dolosa - Crimes materiais tentados 
Assim, suponha-se que, na hipótese apresentada, os tiros disparados por Lucas não tenham atingido João por fatores alheios à vontade daquele. Nesse caso, conforme se observa no Mapa 5, o problema é resolvido na estrutura conceitual do dolo quando se valora a conduta ante a seguinte questão:

1) os meios empregados eram idôneos, capazes de realizar o tipo penal determinado?

Se a resposta for não, encerra-se a operação e estará caracterizado o crime impossível. Isso porque não basta querer realizar o tipo penal, faz-se necessário empregar meios idôneos, capazes de produzi-lo. Caso contrário, segue-se a operação para valorar-se a propriedade material do objeto do tipo penal, colocando a seguinte questão:

2) o objeto material do tipo penal é próprio?

Se a resposta for não, encerra-se a operação e estará caracterizado o crime impossível. Todavia, se a resposta for sim, encerra-se a operação e estará caracterizada a tentativa propriamente dita. Portanto, é o resultado da valoração da conduta concretamente realizada com base nesse referente de valoração que definirá se a mesma configura o crime impossível ou a tentativa.

Não se pode esquecer, também, de que o conteúdo da vontade se estende também às condutas concomitantes (conduta meio e conduta subsidiária) conforme se constata no Mapa 5. Assim, no exemplo anterior, observou-se que, para matar João, Lucas praticou a conduta tipificada no artigo 14, do Estatuto do Desarmamento (porte ilegal de armas de fogo de uso permitido). Ocorre, porém, que nesse caso não há concurso de crimes, uma vez que o porte ilegal de armas configura uma conduta concomitante que está na linha de desdobramento do nexo finalista, integrada ao meio empregado por Lucas para realizar o tipo penal determinado. Nessa hipótese, essa conduta é absorvida pelo nexo finalista e esvaziada de seu conteúdo penal, com base no "princípio da consunção". Essa operação recursiva afasta a incidência do concurso de crimes, dessa forma, o porte ilegal não configura um crime autônomo, mas uma conduta meio, integrada ao homicídio, visto que está na linha de desdobramento do nexo finalista. 
Esse raciocínio foi previamente aplicado na concepção do artigo 15, do Estatuto do Desarmamento, que possibilita a integração do disparo de arma de fogo ao nexo finalista quando essa conduta é praticada com a finalidade de realizar outro crime, como no caso em apreço. Considerando-se que Lucas disparou dois tiros contra a cabeça de João, com a finalidade de matá-lo, e que a vítima foi a óbito em decorrência de hemorragia interna causada pelos projéteis disparados, não há que se falar em concurso de crimes, mas concurso aparente de normas.

O mesmo raciocínio se aplica às lesões corporais, dispostas no art. 129, do CP, produzidas pelos projéteis, as quais constituem conduta concomitante subsidiária, residual, uma vez que não há como matar alguém empregando como meio o disparo de arma de fogo contra a cabeça da vítima sem produzir lesões corporais.

\section{DOLO DIRETO E ERRO SOBRE A PESSOA}

O erro sobre a pessoa (Error in persona) ocorre quando o agente pratica uma conduta típica, conscientemente dirigida à realização de um tipo penal determinado, cuja vítima é a pessoa A. Ocorre, porém, que a conduta é orientada por falsa representação sobre essa pessoa e a conduta típica é objetivamente praticada contra a pessoa Não A. Nessa hipótese, não há erro na execução do tipo penal, os meios empregados são idôneos e o objeto é próprio. Há apenas uma falsa representação da realidade que incide sobre a pessoa.

Os acadêmicos de direito sabem que, quando há um erro sobre a pessoa, as qualidades da pessoa $A$ se projetam sobre a pessoa Não A, consoante disposição do $\S 3^{\circ}$, art. 20, do CP. Todavia, em geral, não conhecem a lógica desse dispositivo, nem que o mesmo constitui um recurso técnico operativo empregado pelo operador do direito para realizar uma operação recursiva de restauração do dolo e imputar o tipo penal ao agente na modalidade dolosa, conforme se observa no Mapa 6.

O erro sobre a pessoa produz três efeitos sobre a estrutura do dolo que resulta na sua desconstituição, consoante o caput do art. 20, do CP. Para ilustrar, 
imagine-se que João foi contratado para matar a pessoa A. Ocorre, porém, que ao ser orientado por falsa representação sobre pessoa, João matou a pessoa Não $A$, irmão gêmeo da pessoa $A$.

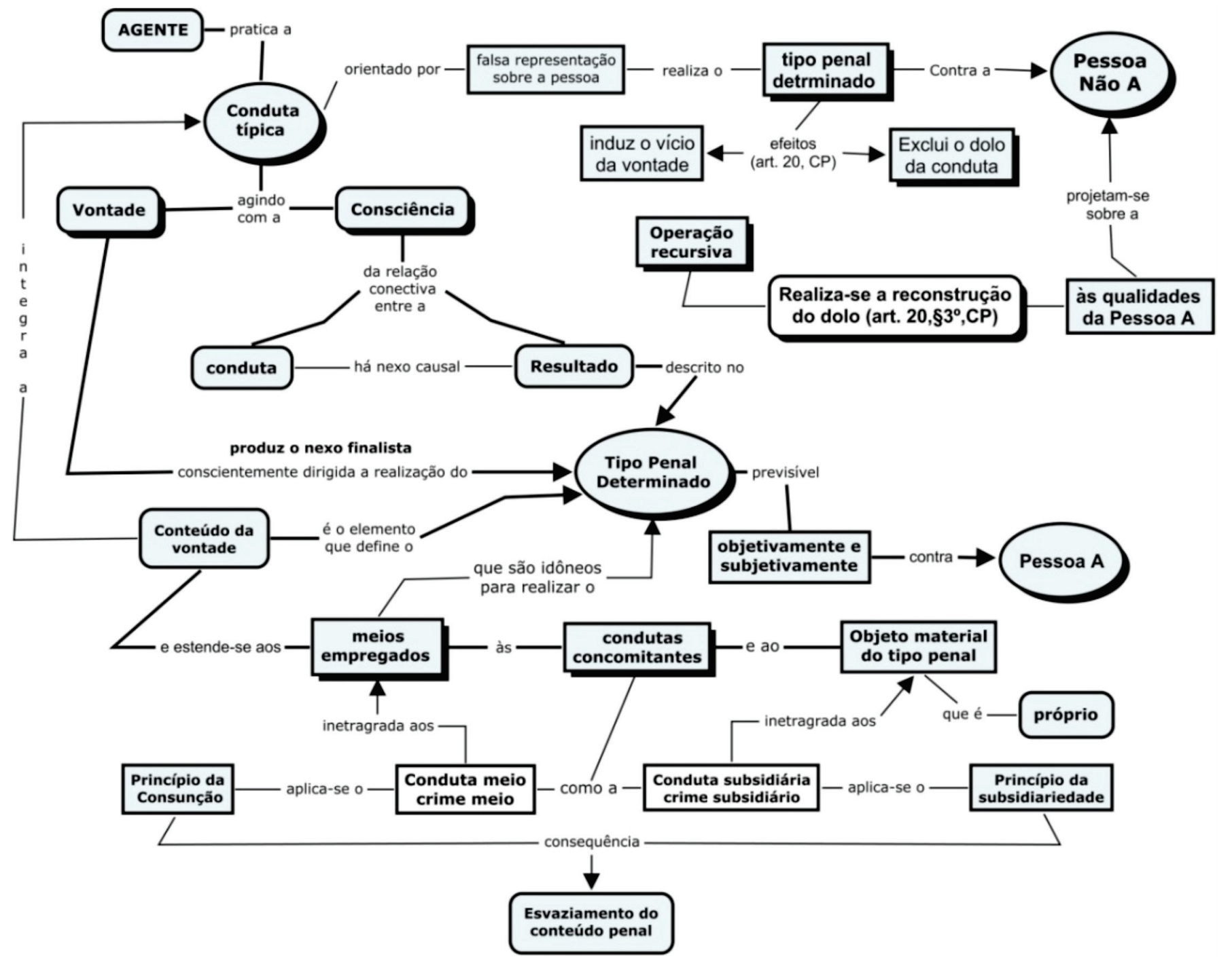

Mapa 6 - Conduta dolosa - Erro sobre a pessoa

O dolo pressupõe conhecimento atualizado do agente no momento que pratica a conduta. Naquele momento João não sabia que estava matando a pessoa Não A. Essa consciência falsa e desatualizada sobre a pessoa contra quem praticou o crime de homicídio produz dois efeitos na estrutura do dolo: (1) induz o vício de vontade e (2) exclui ontologicamente dolo, consoante art. 20, CP.

Para evitar que João seja imputado o homicídio culposo, ante a desconstituição ontológica do dolo direto, faz-se necessário realizar uma operação recursiva de reconstrução racional do dolo. E essa operação realiza-se mediante a projeção das qualidades da pessoa A, sobre a pessoa Não A. Considerando-se, então, que a 
vontade de João é conscientemente dirigida à morte da pessoa $\mathrm{A}$, bem como que racionalmente ele matou a pessoa $A$, a estrutura do dolo é restaurada, tornando logicamente possível a imputação do homicídio na modalidade dolosa.

Conforme se observa no percurso argumentativo deste texto, à medida que a aprendizagem significativa se desenvolve, o conceito de dolo direto torna-se mais elaborado e mais diferenciado dos conceitos a ele relacionados em decorrência das sucessivas interações. Isso porque os elementos existentes na estrutura cognitiva com determinado grau de clareza, estabilidade e diferenciação são percebidos como relacionados, adquirindo novos significados que conduzem a uma reconciliação integrativa, esclarecendo-se, assim, as eventuais semelhanças, diferenças e contradições reais ou aparentes existentes nas relações entre ideias e conceitos ${ }^{29}$. Ou seja, o conceito de dolo direto torna-se apto a servir de âncora para novos conhecimentos, tais como os conceitos de crime impossível, tentativa, erro sobre a pessoa, erro na execução, dolo geral, culpa imprópria e consunção, com os quais está relacionado.

\section{CONSIDERAÇÕES FINAIS}

Com a realização deste trabalho, não se propõe a esgotar o tema abordado. Ao contrário, deseja-se abrir um diálogo e instigar o debate, pois se sabe que a possibilidade de usar o conceito de regiões de valoração ontojurídica como recurso técnico-operativo de análise da conduta típica não esgota todas as possibilidades de interpretações da realidade empírica.

A análise dos casos concretos possibilitará o acréscimo de aspectos da realidade que não se encontram presentes nos referentes originários, corrigindo possíveis irracionalidades, ao mesmo tempo em que torna a análise conduta típica mais tangível, posto que a imputação de significado jurídico-penal a ela impresso funda-se em mecanismos da dedução racional. Assim, faz-se relevante o constante trabalho de construção-reconstrução das regiões e seus referentes de valoração.

29 MOREIRA, Marco Antônio. Aprendizagem significativa: a teoria e textos complementares. p. 18. 
Porfim, cabeobservarque, independentementeda receptividadedas proposições ora apresentadas, há a necessidade de se desenvolver outros mecanismos capazes de tornar a integração conceitual no Direito Penal mais evidente, visto que a atual dispersão constitui um obstáculo à sua aprendizagem sistemática.

\section{REFERÊNCIAS}

AUSUBEL, David P. The Psychology of Meaningful Verbal Learning. New York: Grune \& Stratton, 1963.

BITENCOURT, Cezar Roberto. Manual de direito penal: parte geral. 6. ed. São Paulo: Saraiva, 2012, vol. 1.

BRASIL. Constituição da República Federativa do Brasil (1988). Disponível em: www. legjur.com.

BRASIL. Código Penal Brasileiro. Decreto-Lei 2.848, de 07/12/1940. Disponível em: www. legjur.com.

BRASIL. Lei de Execuções Penais. Lei n. ${ }^{\circ}$ 7.210, de 11/07/1984. Disponível em: www.legjur.com.

CICUTO, Camila Aparecida Tolentino; MENDES Bárbara Chagas; CORREIA Paulo Rogério Miranda. Nova abordagem para verificar como os alunos articulam diferentes materiais instrucionais utilizando mapas conceituais. São Paulo: Revista Brasileira de Ensino de Física. 2013, - jul./set, vol.3, n 3. p. 1-8. Disponível em: www.scielo.br. Acesso em: março/2015.

DURKHEIM, Emile. As Regras do Método sociológico. Trad. Pietro Nassetti. São Paulo: Martin Claret, 2004.

DURKHEIM, Emile. A Divisão do Trabalho Social. Trad. de Eduardo Brandão. São Paulo: Martins Fontes, 1999.

FERREIRA, Paula B.; COHRS, Cibelli R.; DOMENICO, Edvane B. L. Software CMAP TOOLS $®$ para a construção de mapas conceituais: a avaliação dos estudantes de enfermagem. Revista da Escola de Enfermagem da USP; São Paulo, Vol. 46, nº 4, p. 967-972, Ago/2012. Disponível em: www.scielo.br. Acesso em: janeiro/2015.

GOMES, Andréia Patrícia; DIAS-COELHO, Udson Chandler; CAVALHEIRO, Priscila de Oliveira; SIQUEIRA-Batista, Rodrigo. O Papel dos Mapas Conceituais na Educação Médica. Rio de Janeiro: Revista Brasileira de Educação Médica; 2011, Abril/Junho, Vol. 35 n. 2: p. 275-282. Disponível em: www.scielo.br. Acesso em: março/2015. 
MOREIRA, Marco Antônio. Aprendizagem significativa: a teoria e textos complementares. São Paulo: Editora Livraria da Física, 2011.

MOREIRA, Marco e MASINI, Elcie. A aprendizagem significativa: a teoria de David Ausubel. São Paulo: Moraes, 1982.

NOVAK, Joseph Donald y GOWIN, D. Bob. Aprender a aprender. 2. ed. Lisboa: Plátano Edições Técnicas, 1999. Disponível em: www.ir.nmu.org.ua. Acesso em: setembro/2014.

NOVAK, Joseph Donald. Learning, Creating, and Using Knowledge: Concept Maps as Facilitative Tools in Schools and Corporations. 2. ed. Lawrence Erlbaum Associates, Mahwah, 2010. Disponível em: www.books.google.com.br. Acesso em: novembro/2014.

ROXIN, Claus. Estudos de Direito Penal. Trad. Luis Greco. Rio de Janeiro: Renovar, 2012.

ROXIN, Claus. $\mathbf{O}$ conceito de bem jurídico como padrão crítico da norma penal posto à prova. Trad. Susana Aires de Sousa. Revista Portuguesa de Ciência Criminal, Coimbra, Ano 23, n. ${ }^{\circ} 1$ (janeiro-março 2013). p. 7-43.

SOUZA, Nadia Aparecida de; Boruchovitch, Evely. Mapas conceituais: estratégia de ensino/ aprendizagem e ferramenta avaliativa. Educação em Revista, Belo Horizonte, vol.26, nº.3, p. 195-217. Dez/2010. Disponível em: www.scielo.br. Acesso em: fevereiro/2015.

WELZEL, Hans. O novo sistema jurídico-penal: uma introdução à doutrina da ação finalista. 2. ed. Trad. Luiz Regis Prado. São Paulo: Revista dos Tribunais, 2010.

ZAFFARONI, Eugenio Raúl; BATISTA, Nilo et al. Direito Penal Brasileiro Vol. II -Delito: introdução histórica, ação e tipicidade. Rio de Janeiro: Revan, 2010. p. 82.

Recebido em: jul/2015

Aprovado em: dez/2016 